\title{
PERLINDUNGAN TERHADAP PEGAWAI NEGERI SIPIL (PNS) BERDASARKAN KETENTUAN PERATURAN PEMERINTAH NOMOR 11 TAHUN 2017 TENTANG MANAJEMEN PEGAWAI NEGERI SIPIL
}

\author{
${ }^{1}$ Zuhdi Arman, ${ }^{2}$ Padrisan Jamba
}

${ }^{1}$ Fakultas Ilmu Sosial dan Humaniora Universitas Putera Batam, Email: zuhdi@ puterabatam.ac.id ${ }^{2}$ Fakultas Ilmu Sosial dan Humaniora Universitas Putera Batam,Email: padrisan@puterabatam.ac.id

\begin{abstract}
Abstrak
Manajemen Pegawai Negeri Sipil menurut UU Nomor 43 tahun 1999 pasal 1 angka (8) adalah keseluruhan upaya untuk meningkatkan efisiensi, efektivitas, dan derajat profesionalisme penyelenggaraan tugas, fungsi dan kewajiban kepegawaian yang meliputi perencanaan, pengadaan, pengembangan, penempatan, promosi, penggajian, kesejahteraan, dan pemberhentian. Tujuan manajemen Pegawai Negeri Sipil yaitu untuk menjamin penyelenggaraan tugas pemerintahan dan pembangunan secara berdaya guna dan berhasil guna dengan dukungan PNS yang profesional, bertanggungjawab, jujur, dan adil melalui pembinaan yang dilaksanakan berdasarkan sistem prestasi kerja dan sistem karir yang dititik beratkan pada sistem prestasi kerja.
\end{abstract}

Kata kunci : Perlindungan; Manajemen, Pegawai Negeri Sipil

\section{PENDAHULUAN}

\subsection{Latar Belakang Masalah}

Penyusunan dan penetapan kebutuhan PNS dilakukan oleh setiap instansi pemerintah. Dijelaskan pada pasal pasal 5 sampai dengan pasal 11 terkait pelaksanaan penyusunan kebutuhan PNS. Sedangkan terkait penetapan kebutuhan dijelaskan pada pasal 12 sampai dengan 14. Setiap Instansi Pemerintah menyusun kebutuhan jenis jabatan dan jumlah PNS berdasarkan Analisis Jabatan dan 
Analisis Beban Kerja, peta jabatan, dan ketersediaan pegawai. Kegiatan penyusunan tersebut dilakukan untuk jangka waktu 5 tahun dan diperinci setiap tahun berdasarkan prioritas kebutuhan rencana strategi. Penetapan kebutuhan PNS secara nasional setiap tahun anggaran ditetapkan oleh Menteri PAN-RB, setelah memperhatikan pendapat Menteri Keuangan dan pertimbangan teknis Kepala BKN.

Oleh karena itu, penulis tertarik untuk mengkaji melihat dari bagaimana tujuan manajemen Pegawai Negeri Sipil yaitu untuk menjamin penyelenggaraan tugas pemerintahan dan pembangunan secara berdaya guna dan berhasil guna dengan dukungan PNS yang profesional, bertanggungjawab, jujur, dan adil melalui pembinaan yang dilaksanakan berdasarkan sistem prestasi kerja dan sistem karir yang dititik beratkan pada sistem prestasi kerja.

\section{METODE PENELITIAN}

Penelitian ini merupakan penelitian normatif (Normative Approach) yaitu Undang-undang disamping bertumpu pada penelitian normatif, juga ditambah dengan pendekatan teoritis. Selanjutnya dalam menganalisis data digunakan pendekatan kualitatif dan juga didasarkan studi berbasis perpustakaan, yang berarti bahwa bahan yang diperlukan untuk penelitian harus tersedia di perpustakaan, arsip, dan database, undang-undang dan dokumen lainnya (Ibrahim, 2005). 
Program Studi Ilmu Hukum Universitas Putera Batam

\section{PEMBAHASAN DAN HASIL PENELITIAN}

\subsection{Manajemen Pegawai Negeri Sipil}

Pengadaan PNS merupakan kegiatan untuk mengisi kebutuhan Jabatan Administrasi dan/atau Jabatan Fungsional dalam suatu Instansi Pemerintah. Pengadaan PNS di Instansi Pemerintah dilakukan berdasarkan penetapan kebutuhan yang ditetapkan oleh Menteri. Pada pasal 19 sampai dengan pasal 45 dijelaskan secara rinci terkait tahapan pengadaan PNS. Pengadaan PNS dilakukan melalui tahapan perencanaan, pengumuman lowongan, pelamaran, seleksi, pengumuman hasil seleksi, masa percobaan, dan pengangkatan menjadi PNS. Peserta yang lolos seleksi diangkat menjadi calon PNS. Pengangkatan calon PNS ditetapkan dengan keputusan Pejabat Pembina Kepegawaian. Calon PNS wajib menjalani masa percobaan. Masa percobaan dilaksanakan melalui proses pendidikan dan pelatihan terintegrasi untuk membangun integritas moral, kejujuran, semangat dan motivasi, nasionalisme dan kebangsaan, karakter kepribadian yang unggul dan bertanggung jawab, dan memperkuat profesionalisme serta kompetensi bidang. Masa percobaan bagi calon PNS dilaksanakan selama 1 (satu) tahun. Instansi pemerintah wajib memberikan pendidikan dan pelatihan kepada calon PNS selama masa percobaan. Calon PNS yang diangkat menjadi PNS harus memenuhi persyaratan lulus pendidikan dan pelatihan dan sehat jasmani dan rohani. 
Program Studi Ilmu Hukum Universitas Putera Batam

\section{Pangkat dan Jabatan PNS}

Peraturan perundang-undangan Nomor 43 tahun 1999 pasal 17 ayat (2) menyebutkan bahwa pengangkatan PNS dalam suatu jabatan dilaksanakan berdasarkan prinsip profesionalisme sesuai dengan kompetensi, prestasi kerja dan jenjang pangkat yang ditetapkan untuk jabatan itu serta syarat obyektif lainnya tanpa membedakan jenis kelamin, suku, agama, ras atau golongan dan Menurut UU Nomor 5 tahun 2014 pasal 108 tentang pengisian jabatan pimpinan dengan memperhatikan syarat kompetensi, kualifikasi, kepangkatan, pendidikan dan pelatihan, rekam jejak jabatan, dan integritas serta persyaratan jabatan lain sesuai ketentuan peraturan perundang-undangan. ${ }^{1}$

Terkait Pangkat dan Jabatan, menurut PP Manajemen PNS ini, pangkat merupakan kedudukan yang menunjukkan tingkatan jabatan berdasarkan tingkat kesulitan, tanggung jawab, dampak, dan persyaratan kualifikasi pekerjaan yang digunakan sebagai dasar penggajian. Pangkat sebagaimana dimaksud diatur dalam Peraturan Pemerintah yang mengatur mengenai gaji, tunjangan dan fasilitas bagi PNS,” begitu bunyi Pasal 46 ayat (2) PP tersebut.

Disebutkan pada pasal 47 bahwa Jabatan PNS terdiri atas: Jabatan Administrasi (JA), Jabatan Fungsional (JF), dan Jabatan Pimpinan Tinggi (JPT). Nomenklatur Jabatan dan Pangkat JPT Utama dan JPT Madya, menurut PP ini, ditetapkan oleh Presiden atas usul instansi Pemerintah terkait setelah mendapat pertimbangan Menteri PAN-RB. Sementara nomenklatur Jabatan dan Pangkat JPT Pratama, JA,

\footnotetext{
${ }^{1}$ Ben Galus, 2014, Menalar Negara : Perspektif Politik, Birokrasi, Pendidikan, Lingkungan hidup dan Kebudayaan, Yogyakarta : Beta. halaman 476.
} 
dan JF untuk masing-masing satuan organisasi instansi pemerintah ditetapkan oleh pimpinan instansi setelah mendapat persetujuan Menteri PAN-RB. Pengisian Jabatan Pelaksana, JF keahlian jenjang ahli pertama, JF keterampilan jenjang pemula, dan JF keterampilan jenjang terampil, menurut PP ini, dapat dilakukan melalui pengadaan PNS. Adapun pengisian Jabatan administrator, Jabatan pengawas, JF keahlian jenjang ahli utama, JF keahlian jenjang ahli madya, JF keahlian jenjang ahli muda, JF keterampilan jenjang penyelia, JF keterampilan jenjang mahir, dan/atau JPT, dapat dilakukan dengan rekrutmen dan seleksi dari PNS yang tersedia, baik yang berasal dari internal instansi pemerintah maupun PNS yang berasal dari instansi pemerintah lain.

Jenjang JA dari yang paling tinggi ke yang paling rendah pada pasal 50 disebutkan terdiri atas: Jabatan Administrator, Jabatan Pengawas, dan Jabatan Pelaksana.

Selain itu pada manajemen PNS terbaru ini dilakukan penyetaraan terhadap jabatan PNS yaitu:

- Jabatan eselon Ia kepala lembaga pemerintah non kementerian setara dengan Jabatan Pimpinan Tinggi Utama;

- Jabatan eselon Ia dan eselon Ib setara dengan Jabatan Pimpinan Tinggi madya;

- Jabatan eselon II setara dengan Jabatan Pimpinan Tinggi Pratama;

- Jabatan eselon III setara dengan Jabatan Administrator;

- Jabatan eselon IV setara dengan Jabatan Pengawas; dan 
- Jabatan eselon $\mathrm{V}$ dan fungsional umum setara dengan jabatan pelaksana.

\section{Pengembangan Karir PNS}

Pengembangan karier dilakukan berdasarkan kualifikasi, kompetensi, penilaian kinerja, dan kebutuhan instansi pemerintah. Pengembangan karier PNS dijelaskan secara rinci pada pasal 176 sampai dengan pasal 187. Pengembangan karier seorang pegawai perlu dilakukan karena seorang pegawai bekerja dalam suatu organisasi tidak hanya ingin memperoleh apa yang dipunyai hari ini, tetapi juga mengharapkan ada perubahan, ada kemajuan, ada kesempatan yang diberikan kepadanya untuk maju ke tingkat yang lebih tinggi dan lebih baik.

Pengembangan karier pegawai secara umum dapat diartikan sebagai upaya perubahan atau peningkatan karier pegawai dari suatu jabatan lain dalam ruang dan golongan yang berbeda. Utomo memberikan pengertian pengembangan karir sebagai proses pelaksanaan (implementasi) perencanaan karir. Pengembangan karir pegawai bisa dilakukan melalui dua jalur, yakni melalui pendidikan dan latihan (diklat) dan melalui non diklat. Contoh pengembangan karir melalui diklat misalnya menyekolahkan pegawai(di dalam atau di luar negeri), memberi pelatihan (di dalam atau di luar organisasi), memberi pelatihan sambil bekerja (on the job training). Sedangkan, contoh pengembangan karir melalui non diklat seperti memberi penghargaan kepada pegawai berprestasi, mempromosikan ke jabatan yang lebih tinggi, menghukum pegawai, merotasi pegawai ke jabatan lain yang setara dengan jabatan semula. 
Pengembangan karier pegawai dicapai berdasarkan kriteria kemampuan, keahlian dan pengetahuan yang dimiliki pegawai untuk menduduki jenjang jabatan yang lebih tinggi, namun dalam era kompetisi global ini, pengembangan karier lebih bersifat Protean career atau karier yang seringkali berubah sesuai perubahan minat pegawai, nilai-nilai yang dianut, kemampuan dan perubahan di dalam lingkungan kerja. Implikasinya terhadap pola karier pegawai bukan lagi diarahkan untuk mengisi jabatan struktural, tetapi terarah pada keberhasilan pegawai secara psikologis. Hal ini akan memotivasi pegawai yang ingin mencapai sukses karir bukan karena ada peluang naik jabatan melainkan mencapai prestasi dalam karir berdasarkan kemampuannya.

\section{Pola Karir PNS}

Pola karier merupakan pola dasar mengenai urutan penempatan dan/ atau perpindahan PNS dalam dan antar posisi di setiap jenis Jabatan secara berkesinambungan. Pola karier PNS terdiri atas pola karier instansi dan pola karier nasional. Setiap Instansi Pemerintah menyusun pola karier instansi secara khusus sesuai dengan kebutuhan berdasarkan pola karier nasional sedangkan pola karier nasional disusun dan ditetapkan oleh Menteri.

Pola karier atau jalur karier Pegawai Negeri Sipil (PNS) adalah jalur yang dapat dilalui seorang PNS selama pengabdiannya sebagai pegawai. Pola karier adalah salah satu aspek yang mesti ada dalam manajemen karier. Pola karier berguna dalam proses manajemen karier dan talenta pegawai. Para pegawai dan talenta memiliki kejelasan dalam prospek karier ke depan. Jika pola karier 
pegawai ini sudah dimasukkan dalam sistem informasi SDM secara terintegrasi, maka setiap saat seorang pegawai bisa mengetahui di mana posisinya saat ini dan dalam beberapa waktu ke depan ke mana saja ia dapat dirotasi atau dipromosikan dalam rangka pengembangan kariernya.

Satu contoh praktis, seorang wali kota dapat menetapkan pedoman, bahwa untuk menjadi seorang sekretaris daerah di kotanya, seorang pegawai diisyaratkan pernah menduduki paling tidak 3 jabatan kepala dinas dan/atau kepala badan, dan lebih disukai pernah menjadi kepala badan perencanaan pembangunan daerah. Berdasarkan pedoman tersebut, maka seorang pegawai yang dipersiapkan untuk menduduki jabatan sekretaris daerah disiapkan melalui jalur karier untuk menduduki posisi pada tiga kepada dinas/badan. Ini adalah contoh bagaimana pedoman pola karier akan memandu proses manajemen karier dan manajemen talenta pada satu daerah.

Dalam manajemen PNS saat ini pola karier terbagi atas pola karier instansi dan pola karier nasional. Pola karier instansi ditetapkan oleh PPK berdasarkan PP tentang Manajemen PNS. Pola karier nasional diatur lebih jauh oleh pemerintah pusat, Kementerian Pendayagunaan Aparatur Negara dan Reformasi Birokrasi (PAN dan RB), dan diatur lebih lanjut oleh Badan Kepegawaian Negara (BKN). Pada pola karier instansi terutama, juga diatur pola perpindahan jabatan antara jabatan administrasi dan jabatan pimpinan tinggi (struktural) dengan jabatan fungsional. 
Program Studi Ilmu Hukum Universitas Putera Batam

\section{Promosi PNS}

Promosi (promotion) merupakan salah satu langkah dari proses manajemen sumberdaya manusia dalam organisasi. Promosi merupakan salah satu bagian dari kegiatan penempatan, pemindahan, atau pemeliharaan pegawai. Seperti dikatakan oleh Stoner dan Wankel, pemindahan pegawai adalah suatu pergeseran seseorang pegawai dari satu jabatan, tingkatan organisasi, atau tempat ke jabatan, tingkatan, atau tempat lain. Dua jenis pemindahan yang umum adalah :

- "Promosi" yaitu suatu pergeseran ke posisi yang lebih tinggi dalam hierarki organisasi;

- $\quad$ "Pemindahan literal" yaitu pergeseran dari suatu posisi ke posisi yang lain pada tingkatan yang sama.

Siagian mengatakan bahwa pertimbangan senioritas ini ditempuh oleh organisasi untuk dasar promosi adalah :

(1) sebagai penghargaan atas jasa-jasa seseorang paling sedikit dilihat dari segi loyalitas kepada organisasi;

(2) penilaian biasanya bersifat obyektif karena cukup dengan memperbandingkan masa kerja orang-orang tertentu yang dipertimbangkan untuk dipromosikan; dan

(3) mendorong organisasi mengembangan para pegawainya karena pegawai yang paling lama berkarya akhirnya mendapat promosi. Namun demikian promosi atas dasar senioritas belum ini mempunyai kelemahan terutama pada 
Program Studi Ilmu Hukum Universitas Putera Batam

kenyataan bahwa pegawai yang paling senior belum tentu merupakan pegawai yang paling produktif atau paling mampu bekerja.

\section{Mutasi PNS}

Segala perubahan mengenai seseorang Pegawai Negeri Sipil, seperti pengangkatan, pemindahan, pemberhentian, pemensiunan, perunbahan susunan keluarga dan lain-lain. Ruang Lingkup Mutasi Kepegawaian

a. Mutasi pegawai baru

b. Mutasi Calon Pegawai Negeri Sipil

c. Mutasi Pegawai Negeri Sipil : 1) Pengankatan Pegawai Negeri Sipil, 2) Berita acara pengambilan sumpah/janji Pegawai Negeri Sipil, 3) Kartu pegawai

d. Mutasi pendidikan dan pelatihan : 1) Pendidikan dan pelatihan Pra jabatan, 2) Pendidikan dan pelatihan dalam jabatan : Pendidikan dan pelatihan pimpinan, Pendidikan dan pelatihan fungsional, Pendidikan dan pelatihan teknis

e. Mutasi Pendidikan : 1) Peningkatan pendidikan, 2) Tugas belajar

f. Mutasi Jabatan : 1) Pengankatan dalam jabatan, 2) Pembebasab dari jabatan Organik

g. Mutasi Keluarga : Karis/ Karsu / Anak/ Perkawinan / Perceraian

h. Mutasi penghargaan

i. Mutasi hukuman disiplin

j. Mutasi pindah wilayah kerja 
k. Mutasi peninjauan masa kerja

1. Mutasi kenaikan pangkat

m. Mutasi pemberhentian

n. Mutasi Pensiun

o. Mutasi pengujian kesehatan

\section{Penilaian Kinerja PNS}

Upaya untuk melakukan penilaian terhadap kinerja pegawai tidaklah mudah. Berbagai sumber daya, baik tenaga, waktu, dan dana telah dicurahkan untuk dapat memberikan penilaian sesuai dengan kinerja yang dilakukan oleh pegawai tersebut sekaligus menjadi ciri pembeda bagaimana perbedaan tingkat hasil kinerja antara satu pegawai dan pegawai lainnya.

Melalui hasil penilaian kinerja tersebut, pihak atasan atau jajaran pimpinan dapat menggunakannya dapat memberikan semacam reward dan punishment kepada pegawai, termasuk dalam melakukan promosi, mutasi, dan rotasi. Namun demikian, tidak jarang terdengar bahwa penilaian kinerja pegawai ternyata masih di atas kertas semata. Hal ini menyebabkan munculnya persepsi bahwa hasil penilaian kinerja pegawai hanyalah sekadar formalitas belaka. Penilaian kinerja cenderung masih dipandang sebagai hanya sebatas memenuhi prasyarat yang diharuskan oleh pembina kepegawaian.

Munculnya persepsi semacam ini juga biasanya tidaklah merujuk pada satu atau dua contoh kasus semata, tetapi sudah beberapa kali terjadi di lingkungan kerja pegawai. Hal ini tentu menjadi preseden tidak baik bagi 
kondusif kerja dalam organisasi. Bahkan, tidak jarang muncul anggapan bahwa sudah rancangan (setting) awal untuk melakukan promosi, mutasi, dan rotasi sebelum adanya hasil penilaian kinerja.

Indikasi yang sering digunakan oleh sebagian pegawai dalam memberikan label seperti itu adalah sering adanya kejadian yang luar biasa dan tidak pernah diprediksikan sebelumnya. Misalnya, tiba-tiba yang mendapatkan promosi adalah orang tertentu, padahal secara keseharian dan berdasarkan beberapa indikator yang sering digunakan dalam penilaian hal tersebut belum terpenuhi. Kalaupun sudah terpenuhi, masih ada orang lain yang dipandang lebih tinggi dan lebih layak mendapatkan promosi.

Seringkali dalam pandangan mereka adalah orang tertentu yang dinilai kinerjanya kurang baik, bahkan sering melakukan kesalahan fatal justru mendapatkan promosi. Sebaliknya, ada orang yang mereka nilai memiliki kinerja naik dan tidak pernah melakukan kesalahan fatal justru tidak mendapatkan promosi. Akibatnya, hasil kinerja para pegawai hanya menjadi kumpulan dan tumpukan berkas dan file semata. Hal ini menyebabkan munculnya kesan bahwa ada kecenderungan kita berhasil memenuhi syarat penilaian kinerja, tetapi belum mampu sepenuhnya menerapkan hasil penilaian kinerja tersebut dalam melakukan evaluasi dan pengembangan, termasuk dalam pengembangan karier pegawai. Inilah yang membuat munculnya kesan bahwa penilaian kinerja masih sebatas di atas kertas belaka. 
Program Studi Ilmu Hukum Universitas Putera Batam

\section{Penggajian dan Tunjangan PNS}

Gaji adalah sebagai balas jasa dan penghargaan atas prestasi kerja Pegawai Negeri yang bersangkutan. Pada umumnya sistem penggajian dapat digolongkan dalam dua sistem, yaitu sistem skala tunggal dan sistem skala ganda. Sistem skala tunggal adalah system penggajian yang memberikan gaji yang sama kepada pegawai yang berpangkat sama dengan tidak atau kurang memperhatikan sifat pekerjaan yang dilakukan dan beratnya tanggung jawab pekerjaannya. Sistem skala ganda adalah sistem penggajian yang menentukan besarnya gaji bukan saja didasarkan pada pangkat, tetapi juga didasarkan pada sifat pekerjaan yang dilakukan, prestasi kerja yang dicapai dan beratnya tanggung jawab pekerjaannya. Selain kedua sistem penggajian tersebut dikenal juga sistem penggajian ketiga yang disebut sistem skala gabungan, yang merupakan perpaduan antara sistem skala tunggal dan sistem skala ganda. Dalam sistem skala gabungan, gaji pokok ditentukan sama bagi pegawai negeri yang berpangkat sama, di samping itu diberikan tunjangan kepada Pegawai Negeri yang memikul tanggung jawab yang lebih berat, prestasi yang tinggi atau melakukan pekerjaan tertentu yang sifatnya memerlukan pemusatan perhatian dan pengerahan tenaga secara terus-menerus.

Selain gaji pokok, kepada Pegawai Negeri Sipil dapat diberikan :

A. Tunjangan keluarga, yaitu tunjangan suami/isteri dan tunjangan anak yang besaran sesuai dengan peraturan perundang-undangan yang berlaku. 
- Tunjangan suami/isteri diberikan kepada PNS yang telah bersuami/beristeri yaitu sebesar $10 \%$ dari gaji pokok, dengan ketentuan apabila kedua-duanya berkedudukan sebagai PNS maka tunjangan tersebut hanya diberikan kepada salah satu diantaranya yang mempunyai gaji pokok lebih tinggi.

- Tunjangan anak diberikan kepada PNS yang telah mempunyai anak atau anak angkat yang berumur kurang dari 21 tahun, belum pernah kawin, tidak mempunyai penghasilan sendiri dan nyatanyata menjadi tanggungan PNS yang bersangkutan yaitu sebesar $2 \%$ dari gaji pokok untuk tiap-tiap anak sebanyak-banyaknya 2 orang anak sudah termasuk anak angkat.

B. Tunjangan jabatan, adalah sejumlah dana yang diberikan perusahaan kepada karyawan di di samping gaji bulanan. Tunjangan setiap bulannya diberikan bersamaan dengan gaji dan menjadi salah satu komponen penggajian. Tunjangan jabatan mudah didapati di perusahaan swasta maupun pemerintahan.

C. Tunjangan pangan, yaitu Tunjangan pangan untuk PNS adalah tunjangan yang dikenal juga dengan tunjangan beras. Tunjangan ini diberikan kepada PNS dan anggota keluarganya dalam bentuk natura (beras) atau dalam bentuk inatura (uang) dengan besaran yang sesuai dengan ketentuan berlaku.

D. Tunjangan lain-lain. 
Program Studi Ilmu Hukum Universitas Putera Batam

\section{Penghargaan PNS}

Untuk mendorong dan meningkatkan prestasi kerja serta untuk memupuk kesetiaan terhadap Negara, maka kepada PNS yang telah menunjukkan kesetiaan atau telah berjasa terhadap Negara atau yang telah menunjukkan prestasi kerja yang luar biasa akan diberikan penghargaan oleh Pemerintah. Penghargaan yang dimaksud dapat berupa tanda jasa, kenaikan pangkat istimewa, atau bentuk penghargaan lainnya, seperti surat pujian, penghargaan yang berupa materiil, dan lain-lain.

Pengertian penghargaan Pegawai Negeri Sipil adalah suatu kehormatan yang diberikan oleh Pemerintah Daerah kepada Seseorang atau Badan karena jasajasanya dinilai bermanfaat bagi Pemerintah Daerah, pembangunan dan masyarakat. Dengan demikian, penghargaan dari Pemerintah Daerah ini tidak hanya diberikan kepada PNS saja tetapi juga kepada Badan Hukum Publik atau Badan Hukum Perdata, Lembaga, Dinas, Instansi, Organisasi Sosial yang melakukan kegiatan di daerah, akan tetapi dalam tulisan ini dikhususkan Penghargaan Pemerintah Daerah kepada PNS saja. Maksud dan tujuan pemberian penghargaan adalah :

a) Memberikan pengakuan berupa penghargaan kepada Seseorang atau Badan yang telah berjasa dalam bidang cipta, karsa dan karya yang bermanfaat bagi daerah;

b) Memberi motivasi kepada setiap warga masyaraka untuk berperan serta aktif dalam pembangunan, baik yang bersifat fisik materiil maupun 
mental spiritual sehingga dapat terwujud kondisi masyarakat yang dinamis dan kreatif sesuai dengan bidang tugasnya masing-masing.

Syarat umum untuk dapat memperoleh Tanda Kehormatan Satyalancana Karya Satya adalah : PNS, memiliki integritas motal dan keteladanan, berjasa terhadap bangsa dan Negara, berkelakuan baik, setia dan tidak mengkhianati bangsa dan Negara, tidak pernah dipidana penjara berdasarkan putusan pengadilan yang telah memperoleh kekuatan hokum tetap karena melakukan tindak pidana yang diancam dengan pidana penjara paling singkat 5 (lima) tahun.

Pasal 22 Peraturan Pemerintah Nomor 35 Tahun 2010 tentang Pelaksanaan Undang-Undang Nomor 20 Tahun 2009 tentang Gelar, Tanda Jasa, dan Tanda Kehormatan, mengatur Syarat khusus bagi seorang PNS untuk memperoleh Tanda Kehormatan Satyalancana Karya Satya adalah PNS yang telah bekerja dengan penuh kesetiaan kepada Pancasila, UUD RI 1945, Negara dan pemerintah serta dengan penuh pengabdian, kejujuran, kecakapan, dan disiplin secara terus menerus paling singkat 10 (sepuluh) tahun, 20 (dua puluh) tahun, atau 30 (tiga puluh) tahun, dengan ketentuan :

a) Dalam masa bekerja secara terus menerus, PNS yang bersangkutan tidak pernah dijatuhi hukuman disiplin tingkat sedang atau berat berdasarkan peraturan perundang-undangan atau yang tidak pernah mengambil cuti di luar tanggungan Negara; 
b) Penghitungan masa kerja bagi PNS yang pernah dijatuhi hukuman disiplin sedang atau berat dimulai sejak diterbitkannya surat keputusan telah menjalankan hukuman disiplin atau kembali bekerja di instansi;

c) Penghitungan masa kerja dihitung sejak PNS diangkat menjadi calon PNS.

- Setiap penerima Tanda Kehormatan Satyalancana Karya Satya memiliki kewajiban :

a. Menjaga nama baik diri dan jasa yang telah diberikan kepada bangsa dan Negara;

b. Menjaga dan memelihara symbol dan/atau lencana Tanda Kehormatan;

c. Memberikan keteladanan dan menumbuhkan semangat masyarakat untuk berjuang dan berbakti kepada bangsa dan Negara.

\section{Disiplin PNS}

Keberhasilan suatu organisasi dalam mencapai sesuatu tujuan selain sangat ditentukan oleh dan mutu profesionalitas juga ditentukan oleh disiplin para anggotanya. Bagi aparatur pemerintahan disiplin tersebut mencakup unsur-unsur ketaatan, kesetiaan, kesungguhan dalam menjalankan tugas dan kesanggupan berkorban, dalam arti mengorbankan kepentingan pribadi dan golongannya untuk kepentingan negara dan masyarakat 
Dalam Pasal 29 Undang-undang Nomor 8 Tahun 1974 tentang Pokok-pokok Kepegawaian sebagaimana telah diubah dengan Undang-undang Nomor 43 dinyatakan bahwa "Dengan tidak mengurangi ketentuan dalam peraturan perundang-undangan pidana, maka untuk menjamin tata tertib dan kelancaran pelaksanaan tugas, diadakan Peraturan Disiplin Pegawai Negeri Sipil”.

Peraturan Disiplin Pegawai Negeri Sipil adalah peraturan yang mengatur mengenai kewajiban, larangan, dan sanksi apabila kewajiban tidak ditaati atau larangan dilanggar oleh Pegawai Negeri Sipil. Peraturan Disiplin Pegawai Negeri Sipil diatur dalam Peraturan Pemerintah Nomor 30 Tahun 1980 tentang "Peraturan Disiplin Pegawai Negeri Sipil". Dalam Peraturan Disiplin Pegawai Negeri Sipil diatur ketentuan-ketentuan mengenai:

1. Kewajiban,

2. Larangan,

3. Hukuman disiplin,

4. Pejabat yang berwenang menghukum,

5. Penjatuhan hukuman disiplin,

6. Keberatan atas hukuman disiplin,

7. Berlakunya keputusan hukuman disiplin.

- Kewajiban :

Pasal 2 Peraturan Pemerintah Nomor 30 Tahun 1980 mengatur kewajibankewajiban yang harus ditaati oleh setiap Pegawai Negeri Sipil, sebagai berikut. Setiap Pegawai Negeri Sipil wajib, 
1. Setia dan taat sepenuhnya kepada Pancasila, Undang-undang Dasar 1945, Negara, dan Pemerintah,

2. Mengutamakan kepentingan Negara di atas kepentingan golongan atau diri sendiri, serta menghindarkan segala sesuatu yang dapat mendesak kepentingan Negara oleh kepentingan golongan, diri sendiri, atau pihak lain,

3. Menjunjung tinggi kehormatan dan martabat Negara, Pemerintah, dan Pegawai Negeri Sipil,

4. Mengangkat dan menaati Sumpah/Janji Pegawai Negeri Sipil dan Sumpah/Janji jabatan berdasarkan peraturan perundang-undangan yang berlaku,

5. Menyimpan rahasia negara dan atau rahasia jabatan dengan sebaikbaiknya,

6. Memperhatikan dan melaksanakan segala ketentuan Pemerintah, baik yang langsung menyangkut tugas kedinasannya maupun yang berlaku secara umum,

7. Melaksanakan tugas kedinasan dengan sebaik-baiknya dan dengan penuh pengabdian, kesadaran, dan tanggung jawab,

8. Bekerja dengan jujur, cermat, dan bersemangat untuk kepentingan Negara, Memelihara dan meningkatkan keutuhan, kekompakan, persatuan, dan kesatuan Korps Pegawai Negeri Sipil, 
9. Segera melaporkan kepada atasannya, apabila mengetahui ada hal yang dapat membahayakan atau merugikan Negara atau Pemerintah, terutama di bidang keamanan, keuangan, dan materiel,

10. Menaati ketentuan jam kerja,

11. Menciptakan dan memelihara suasana kerja yang baik,

12. Menggunakan dan memelihara barang-barang milik Negara dengan sebaik-baiknya,

13. Memberikan pelayanan dengan sebaik-baiknya kepada masyarakat menurut bidang tugasnya masing-masing,

14. Bertindak dan bersikap tegas, tetapi adil dan bijaksana terhadap bawahannya,

15. Membimbing bawahannya dalam melaksanakan tugasnya,

\section{Pemberhentian PNS}

Kepegawaian Pemberhentian dalam manajemen PNS tidak semata-mata pemutusan hubungan kerja, namun ada hal lain yang menyebabkan pegawai yang diberhentikan mendapatkan hak yang berbeda dari karyawan perusahaan. Dilihat dari cara pemberhentian, ada dua macam pemberhentian PNS, yaitu pemberhentian dengan hormat dan tidak dengan hormat.

- Pemberhentian PNS Dengan Hormat

PNS yang diberhentikan dengan hormat diberikan hak-hak kepegawaian berdasarkan peraturan perundang-undangan yang berlaku. 
PNS yang diberhentikan dengan hormat sebagai PNS karena mencapai batas usia pensiun (BUP) berhak atas pensiun apabila ia memiliki masa kerja pensiun sekurang-kurangnya 10 tahun kecuali jika yang bersangkutan sakit. PNS diberhentikan dengan hormat dengan mendapatkan hak-hak apabila berdasarkan surat keterangan tim penguji kesehatan dinyatakan sebagai berikut:

1. Tidak dapat bekerja lagi dalam semua jabatan negeri karena kesehatannya. Pegawai yang seperti ini mendapatkan hak pensiun tanpa terikat masa kerja pensiun apabila oleh tim penguji kesehatan dinyatakan tidak dapat bekerja lagi dalam semua jabatan negeri karena kesehatannya yang disebabkan oleh dan karena ia menjalankan kewajiban jabatan. Apabila penyebabnya bukan disebabkan oleh dan karena ia menjalankan kewajiban jabatan maka hak pensiun akan diberikan apabila yang bersangkutan telah memiliki masa kerja pensiun sekurang-kurangnya empat tahun.

2. Menderita penyakit atau kelainan yang berbahaya bagi dirinya sendiri dan atau lingkungan kerjanya.

3. Setelah berakhirnya cuti sakit, belum mampu bekerja kembali.

- Pemberhentian PNS Tidak Dengan Hormat

Pemberhentian PNS tidak dengan hormat akan mengakibatkan yang bersangkutan kehilangan hak pensiun. Pemberhentian tidak dengan hormat dapat disebabkan oleh beberapa hal, seperti berikut ini: 
1. Melanggar sumpah/janji/peraturan disiplin.

2. Dihukum penjara berdasarkan keputusan pengadilan yang telah mempunyai kekuatan hukum yang tetap karena melakukan tindak pidana dengan ancaman hukuman pidana penjara setinggi-tingginya empat tahun atau yang lebih berat.

3. Melakukan usaha yang bertujuan mengubah Pancasila dan atau UUD 1945 atau terlibat melakukan kegiatan yang menentang negara atau pemerintah.

4. Meninggalkan tugasnya secara tidak sah selama enam bulan terusmenerus.

\section{Jaminan Pensiun dan Jaminan Hari Tua bagi Pegawai Negeri Sipil}

Jaminan pensiun dan jaminan hari tua diatur dalam ketentuan Pasal 304Pasal 307 Peraturan Pemerintah Nomor 11 Tahun 2017 tentang Manajemen Pegawai Negeri Sipil.

- Sumber Pembiayaan Pensiun

Jaminan pensiun dan jaminan hari tua yang diberikan kepada pegawai negeri sipil mencakup jaminan pensiun dan jaminan hari tua yang diberikan dalam program jaminan sosial nasional, yang sumber pembiayaannya berasal dari pemerintah selaku pemberi kerja dan iuran pegawai negeri sipil yang bersangkutan. 
- Kategori Penerima Jaminan Pensiun

Pegawai negeri sipil yang berhak menerima jaminan pensiun dan jaminan hari tua adalah pegawai negeri sipil yang memenuhi syarat dan ketentuan sebagaimana tersebut di bawah ini, yaitu:

1. Pegawai negeri sipil yang diberhentikan dengan hormat karena meninggal dunia.

2. Pegawai negeri sipil yang diberhentikan dengan hormat atas permintaan sendiri apabila telah berusia 45 (empat puluh lima) tahun dan masa kerja paling sedikit 20 (dua puluh) tahun.

3. Pegawai negeri sipil yang diberhentikan dengan hormat karena mencapai batas usia pensiun apabila telah memiliki masa kerja untuk pensiun paling sedikit 10 (sepuluh) tahun.

4. Pegawai negeri sipil yang diberhentikan dengan hormat karena perampingan organisasi atau kebijakan pemerintah yang mengakibatkan pensiun dini apabila telah berusia paling sedikit 50 (lima puluh) tahun dan masa kerja paling sedikit 10 (sepuluh) tahun.

5. Pegawai negeri sipil yang diberhentikan dengan hormat karena dinyatakan tidak dapat bekerja lagi dalam jabatan apapun disebabkan keadaan jasmani dan/atau rohani yang oleh dan karena menjalankan kewajiban jabatan tanpa mempertimbangkan usia dan masa kerja.

6. Pegawai negeri sipil yang diberhentikan dengan hormat karena dinyatakan tidak dapat bekerja lagi dalam jabatan apapun disebabkan 
keadaan jasmani dan atau rohani yang bukan oleh dan karena menjalankan kewajiban jabatan, apabila telah memiliki masa kerja untuk pensiun paling singkat 4 (empat) tahun.

\subsection{Perlindungan Terhadap Pegawai Negeri Sipil}

Perlindungan terhadap Pegawai Negeri Sipil (PNS) diatur dalam ketentuan 308 Peraturan Pemerintah Nomor 11 Tahun 2017 tentang Manajemen Pegawai Negeri Sipil.

Dalam uraian ini disampaikan mengenai:

1. Bentuk perlindungan bagi pegawai negeri sipil

2. Kewajiban pegawai negeri sipil

Perlindungan merupakan hak seorang pegawai negeri sipil sebagaimana disebutkan dalam ketentuan Pasal 21 Undang-Undang Nomor 5 Tahun 2014 tentang Aparatur Sipil Negara. Pegawai Negeri Sipil (PNS) sebagai aparatur negara mendapat perlindungan dari pemerintah. Perlindungan yang wajib diberikan oleh pemerintah kepada pegawai negeri sipil adalah berupa: ${ }^{2}$

1. Jaminan kesehatan.

2. Jaminan kecelakaan kerja.

3. Jaminan kematian.

4. Bantuan hukum.

${ }^{2}$ Wijayanti, Asri, 2013, Hukum Ketenagakerjaan Pasca Reformasi, Sinar Grafika, Jakarta. Halaman 19. 
Program Studi Ilmu Hukum Universitas Putera Batam

\section{PENUTUP}

\subsection{Simpulan}

Berdasarkan pembahasan diatas maka dapat disimpulkan :

1. Manajemen dalam Pengadaan PNS merupakan kegiatan untuk mengisi kebutuhan Jabatan Administrasi dan/atau Jabatan Fungsional dalam suatu Instansi Pemerintah. Pengadaan PNS di Instansi Pemerintah dilakukan berdasarkan penetapan kebutuhan yang ditetapkan oleh Menteri. Pada pasal 19 sampai dengan pasal 45 dijelaskan secara rinci terkait tahapan pengadaan PNS. Pengadaan PNS dilakukan melalui tahapan perencanaan, pengumuman lowongan, pelamaran, seleksi, pengumuman hasil seleksi, masa percobaan, dan pengangkatan menjadi PNS.

2. Perlindungan terhadap Pegawai Negeri Sipil (PNS) diatur dalam ketentuan 308 Peraturan Pemerintah Nomor 11 Tahun 2017 tentang Manajemen Pegawai Negeri Sipil. Perlindungan merupakan hak seorang pegawai negeri sipil sebagaimana disebutkan dalam ketentuan Pasal 21 UndangUndang Nomor 5 Tahun 2014 tentang Aparatur Sipil Negara. Pegawai Negeri Sipil (PNS) sebagai aparatur negara mendapat perlindungan dari pemerintah.

\subsection{Saran}

Sebaiknya selain perlindungan yang diberikan kepada PNS, kesejahteraan PNS juga perlu diperhatikan oleh pemerintah, dengan masih minimnya gaji dan tukin yang didapatkan oleh PNS, semoga bisa ditingkatkan. 
Program Studi Ilmu Hukum Universitas Putera Batam

\section{DAFTAR PUSTAKA}

Ben Galus, 2014, Menalar Negara : Perspektif Politik, Birokrasi, Pendidikan, Lingkungan hidup dan Kebudayaan, Yogyakarta : Beta. halaman 476.

Husen, 2011, Hambatan Penegakkan Disiplin PNS, melalui http://memajukannegeridanbangsa.blogspot.com/2011/1 0/asas-hukumadministrasi-negara.html?m=1, diakses tanggal 14 Mei 2021.

Peraturan Pemerintah Nomor 11 Tahun 2017 tentang Manajemen Pegawai Negeri Sipil.

Wijayanti, Asri, 2013, Hukum Ketenagakerjaan Pasca Reformasi, Sinar Grafika, Jakarta. 